\title{
THE ROLE OF LEADERSHIP IN INNOVATION PERFORMANCE: TRANSACTIONAL VERSUS TRANSFORMATIONAL STYLE
}

\author{
Dewiana Novitasari ${ }^{1}$, Nana Supiana ${ }^{2}$, Heri Supriatna ${ }^{3}$, Muhamad Agung Ali Fikri $^{4}$, Masduki Asbari ${ }^{5}$ \\ ${ }^{1,4}$ Sekolah Tinggi Ilmu Ekonomi Insan Pembangunan, Tangerang, Indonesia \\ ${ }^{2,5}$ Sekolah Tinggi Manajemen Informatika dan Komputer Insan Pembangunan, Tangerang, Indonesia \\ ${ }^{3}$ Universitas Mercu Buana, Jakarta, Indonesia \\ ${ }^{5}$ Universitas Pelita Harapan, Jakarta, Indonesia \\ Correspondence email: ${ }^{1}$ dhewiediosa@gmail.com
}

\begin{abstract}
The purpose of this study was to examine the effect of transactional and transformational on the innovation performance of lecturers. The population of this research is all lecturers at a private university in Tangerang totaling 180 people. The research sample used a random sampling method. The data used are primary data collected through a questionnaire. The number of returned and valid questionnaires was 120 samples. The data is processed using Structural Equating Model (SEM). The results of the study conclude that transactional and transformational leadership have a positive impact on the innovation performance of lecturers. This study proposes a model to improve the performance of lecturers in Tangerang through improving leadership practices in universities. This study can pave the way to improve the readiness of lecturers in facing the 4.0 education era.
\end{abstract}

Keywords: era 4.0; lecture performance; performance innovation; transformational leadership; transactional leadership

\section{ABSTRAK}

Tujuan penelitian ini adalah untuk menguji pengaruh transaksional dan transformasional terhadap kinerja inovasi dosen. Populasi penelitian ini adalah seluruh dosen pada salah satu universitas swasta di Tangerang berjumlah 180 orang. Sampel penelitian menggunakan random sampling method. Data yang digunakan adalah data primer yang dikumpulkan melalui kuesioner. Jumlah kuesioner yang kembali dan valid sebanyak 120 sampel. Data diolah dengan menggunakan Structural Equating Model (SEM). Hasil penelitian menyimpulkan bahwa kepemimpinan transaksional dan transformasional berpengaruh positif terhadap kinerja inovasi dosen. Penelitian ini mengusulkan model untuk meningkatkan kinerja dosen di Tangerang melalui peningkatan praktik kepemimpinan di perguruan tinggi. Kajian ini dapat membuka jalan untuk meningkatkan kesiapan dosen dalam menghadapi era pendidikan 4.0.

Kata kunci: era 4.0; inovasi kinerja; kepemimpinan transformasional; kepemimpinan transaksional; lecture performance

\section{ARTICLE INFORMATION}

Article History: submitted: February 4, 2021; revised: April 7, 2021; accepted: Mei 28, 2021

JEL Classification: 015

How to Cite: Novitasari, D., Supiana, N., Supriatna, H., Fikri, M. A. A., \& Asbari, M. (2021). The Role of Leadership in Innovation Performance: Transactional Versus Transformational Style. JIMFE (Jurnal IImiah Manajemen Fakultas Ekonomi), 7(1), 27-36. https://doi.org/10.34203/jimfe.v7i1.2981 


\section{INTRODUCTION}

How do lecturers understand their leaders? Do they take it as transformational or transactional leaders? How does it relate to the innovation capabilities of lecturers? Some researchers have investigated the relationship between leadership style and innovation, both in educational settings (Al-Husseini et al., 2019; Al-Mansoori \& Koç, 2019; Elrehail, 2018), as well as in a non-educational environment (Wang et al., 2018; Wu \& Hu, 2018). However, important factors are often left out in previous investigations, the lecturers' perceptions of the comparison between the two types of leadership are most widely known and practiced by organizational leaders, both educational and non-educational. The current study aims to examine the influence of transactional and transformational leadership types. As well as analyzing the ratio between the two types of leadership, especially in the world of education, namely private university in Tangerang.

Over the last decade, university has made fundamental changes in areas such as curriculum development, the role of students and lecturers, and learning strategy. These changes have brought about changes in the philosophy that dominate the field of educational leadership (Asbari et al., 2021). As is Leithwood \& Jantzi (2009) suggest that a form of instructional leadership is appropriate with the world of education, both in the 1980s and 1990s. However, the changes made during the 1990s could not be overcome by the function of the leader as an instructional leader. The concept of transformational leadership has gradually begun to shift the concept of instructional leadership, as the expectation of the education world for leaders to bring visionary leadership types into organizations. A mandate difficult for instructional leaders to fulfill. Leithwood \& Jantzi (2009) also shows that the leader is successful in their work have used various mechanisms to motivate and activate their staff to bring about change in their university culture.

Referring to transformational leadership, Burns in 1978 described followers and their leaders as inspiring each other to achieve "higher levels" of morality and motivate justice and equality (Asbari, 2020). Whereas the transactional leadership type refers to the exchange relationship between their leaders and followers. Each of them "makes a deal" out of the expectation of meeting each other's interests and this is the leader's way of maintaining performance by satisfying the needs of followers (Asbari et al., 2020) indicated that transformational leadership binds leaders and followers in a collaborative process and thus contributes to the performance of the entire organization. Transactional leadership, meanwhile, does not bind leaders and followers in any way of collaboration. Therefore, this type of leadership produces a routine, uncreative but stable organizational environment. In contrast to transformational leadership which requires a responsive attitude and an innovative environment. The perception of this leadership style contains an assessment that transformational leadership is described as more beneficial than transactional leadership.

\section{LITERATURE REVIEW AND HYPOTHESIS DEVELOPMENT}

\section{Transactional and Transformational Leadership}

Invalidating Burns' leadership concept, Bass (1985) developed the Multifactor Leadership Questionnaire (MLQ). By performing factor analysis, Bass was able to identify three sub-factors of transformational leadership that were labeled charisma, personal consideration, and intellectual stimulation. Bass also identified two subfactors of transactional leadership that were labeled contingent reward and management by exception. According to Bass, charisma is the individual's ability to arouse followers and lead them to follow the leader's vision and mission. Personal consideration is a leader's ability to pay personal attention to followers, while intellectual stimulation the leader's ability to motivate followers to think of innovative and unusual solutions to various problems at hand. Later, Bass \& Avolio (2000) added another factor, namely inspiration to describe transformational leadership. However, the ability 
to inspire is thought to be closely related to charisma and is therefore often seen as a constituent of the same.

Leithwood and Jantzi (2000) identified six main characteristics of transformational educational leaders, namely building the vision and goals of university, providing intellectual stimulation, offering individualized support, symbolizing professional practices and values, demonstrating high performance expectations, and developing structures to foster participation in decisions. Contingent reward, one subfactor of transactional leadership, relating to situations in which leaders give rewards to followers for completing the agreed task. Management by exception is another subfactor that describes transactional leadership, relating to situations where the leader only responds in case of a problem. Then, this Factor is contained in two forms: passive and active (Bass \& Avolio, 1990). This subfactor, management by exception, seems negative as leadership attributes. In educational settings, Transactional leadership has been described as having four dimensions, namely staffing, instructional support, monitoring school activities, and community focus (Leithwood \& Jantzi, 2000).

\section{Innovation performance}

Anning-Dorson (2016) offers that innovation in service companies can come from multiple sources and service companies seek innovation from within their operations; from the market (external environment) and customers. Innovation is the practical application of an idea into a new product or process. Innovation is a condition in goods and services, even ideas that are considered something new (Reguia, 2013). Innovation capabilities are considered as valuable assets for the company to provide and maintain a competitive advantage and in the implementation of all strategies. Innovation capabilities facilitate companies to rapidly introduce new products and adopt new systems but are essential to a factor to feed ongoing competition. Innovation performance can be described as a combination of assets and resources. It, therefore, requires a wide variety of resources, assets, and capabilities to propel success in a rapidly changing environment (Rajapathirana \& Hui, 2018). According to Rajapathirana \& Hui (2017) innovation performance is defined as (1) the capacity to develop new products that meet market needs; (2) the capacity to apply appropriate process technology to produce these new products; (3) the capacity to develop and adopt new products and processing technologies to meet future needs; (4) and the capacity to respond to deliberate technology activities and unforeseen opportunities created by competitors. In this study, the variable definition and dimensions of variable innovation performance were adapted from the research of Rajapathirana \& Hui (2017), namely: organizational culture, knowledge, and customer and employee engagement.

Based on the theoretical study and previous research above, the research model is as in Figure 1. While the research hypothesis is as follows.

\section{$\mathrm{H}_{1}$ : transactional leadership has an effect on the innovation performance of lecturers}

$\mathrm{H}_{2}$ : transformational leadership has an effect on the innovation performance of lecturers

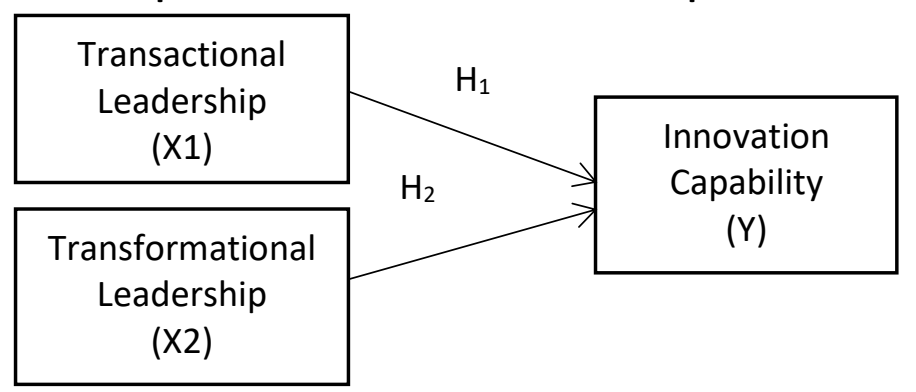

Figure 1. Research Model 


\section{RESEARCH METHODS}

\section{Operational Definition of Variables and Indicators}

The method used in this research is the quantitative method. The population in this study were 182 lecturers of private university in Tangerang. Sample obtained using random sampling technique. Data collection was carried out by distributing questionnaires to all lecturers of university institutions. From 182 questionnaires were e-mailed to all lecturers as the population., 120 questionnaires were returned, which formed a response rate of $60.2 \%$.

The instrument used to measure transactional variables (X1.1-X1.5) and transformational leadership (X2.1-X2.5) was adapted from research and validation by (Bogler, 2001), with each variable of 5 items. While the instrument used to measure variable innovation performance was 3 items (Y1-Y3) which were adapted from research of Rajapathirana \& Hui (2018b) that has been validated by (Sasono \& Novitasari, 2020). The questionnaire is designed closed except for questions/statements regarding the identity of the respondent in the form of a semi-open questionnaire. Each closed question/statement item is given five answer options, namely: strongly agree (SA) score 5, agree (A) score 4, neutral (N) score 3, disagree (DA) score 2, and strongly disagree (SDA) score 1 . The method for processing data is by using PLS.

\section{RESULTS AND DISCUSSION}

\section{Statistic Descriptive}

From the table the results of statistical tests show that most of the research respondents are in the age range of 30 to 40 years. Most of the research respondents had less than five years of experience as a lecturer. In addition, the average education of the respondents is a master's degree.

Table 1. Sample Description

\begin{tabular}{llrc}
\hline \multicolumn{2}{c}{ Criteria } & Total & \% \\
\hline Age (as of & $<30$ years & 12 & $10 \%$ \\
March 2020) & $30-40$ & 86 & $72 \%$ \\
& $\begin{array}{l}\text { years } \\
\text { > 40 years }\end{array}$ & 22 & $18 \%$ \\
The tenure as & $<5$ years & 69 & $58 \%$ \\
a lecturer & 5-10 years & 35 & $29 \%$ \\
& $>10$ years & 16 & $13 \%$ \\
Highest & S2 & 94 & $78 \%$ \\
diploma & S3 & 26 & $22 \%$ \\
\hline
\end{tabular}

\section{Convergent Validity Testing}

A convergent validity test is done by looking at the loading factor value of each indicator against the construct. In most references, a factor weight of 0,5 or more is considered to have sufficiently strong validation to explain latent constructs. In this study, the minimum acceptable loading factor is 0,5 , provided that the AVE value of each construct is $>0,5$ (Ghozali, 2014). 


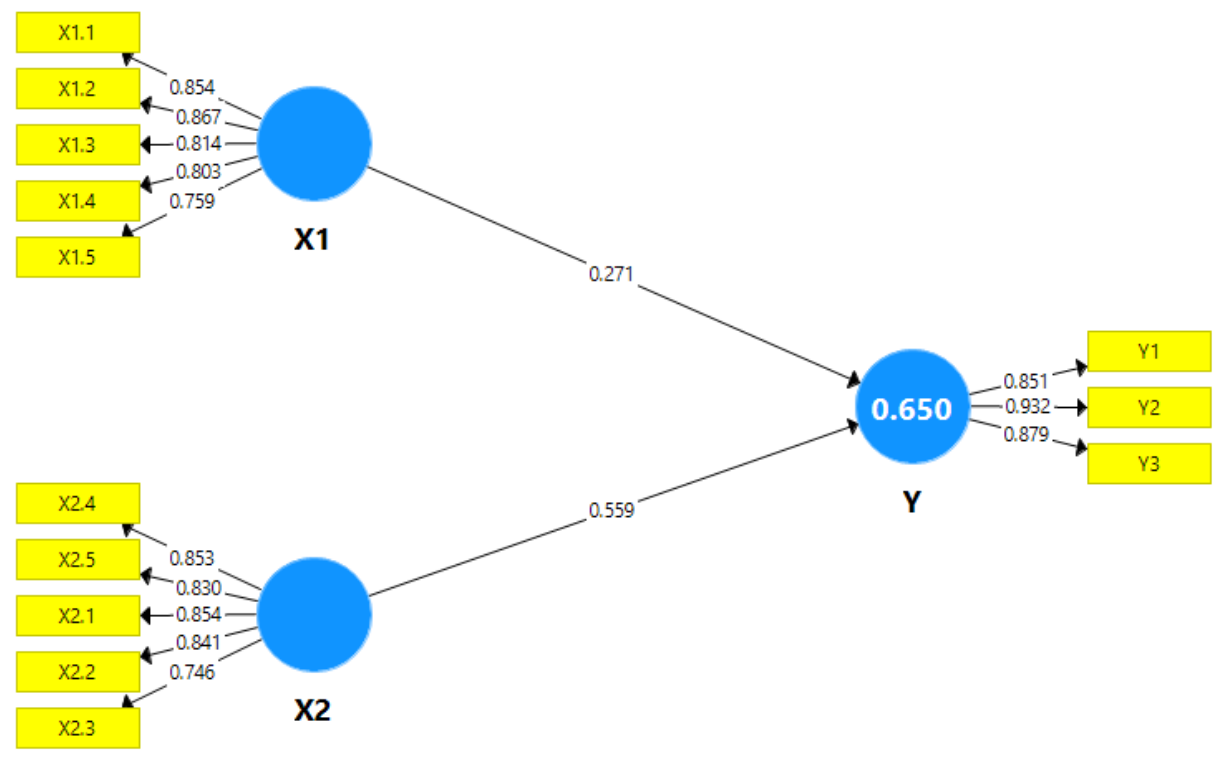

Figure 2. Valid model

Based on the estimation results of the PLS model in the picture above, all indicators have a loading factor value above 0,5 so that the model has met the convergent validity requirements. Apart from looking at the loading factor value of each indicator, convergent validity was also assessed from the AVE value of each construct. The AVE value for each construct of this study is above 0,5 . So the convergent validity of this research model has met the requirements. The value of loadings, Cronbach's alpha, composite reliability, and AVE for each complete construct can be seen in Table 2 .

\section{Discriminant Validity Testing}

Discriminant validity is done to ensure that each concept of each latent variable is different from other latent variables. The model has good discriminant validity if the AVE squared value of each exogenous construct (the value on the diagonal) exceeds the correlation between this construct and other constructs (values below the diagonal) (Ghozali, 2014). The results of discriminant validity testing using the AVE square value, namely by looking at the Fornell-Larcker Criterion Value are obtained as referred to in Table 3. The results of the discriminant validity test in Table 3 above show that all constructs have a square root value of AVE above the correlation value with other latent constructs (through FornellLarcker criteria) so that it can be concluded that the model has met discriminant validity.

Table 2. Discriminant Validity

\begin{tabular}{lccc}
\hline \multicolumn{1}{c}{ Variables } & $\mathbf{X 1}$ & $\mathbf{X 2}$ & $\mathbf{Y}$ \\
\hline Transactional Leadership (X1) & $\mathbf{0 , 8 2 0}$ & & \\
Transformational leadership (X2) & 0,872 & $\mathbf{0 , 8 2 6}$ & \\
Innovation performance (Y) & 0,758 & 0,795 & $\mathbf{0 , 8 8 8}$ \\
\hline
\end{tabular}




\section{Construct Reliability Testing}

The construct reliability can be assessed from the Cronbach's alpha value and the composite reliability of each construct. The recommended composite reliability and Cronbach's alpha values are more than 0,7 (Ghozali, 2014). The reliability test results in table 2 above show that all constructs have composite reliability and Cronbach's alpha values greater than $0,7(>0,7)$. In conclusion, all constructs have met the required reliability.

Table 3. Items Loadings, Cronbach's Alpha, Composite Reliability, and Average Variance Extracted (AVE)

\begin{tabular}{lccccc}
\hline \multicolumn{1}{c}{ Variables } & Items & Loadings & $\begin{array}{c}\text { Cronbach's } \\
\text { Alpha }\end{array}$ & $\begin{array}{c}\text { Composite } \\
\text { Reliability }\end{array}$ & AVE \\
Transactional Leadership (X1) & X1.1 & 0,854 & 0,878 & 0,911 & 0,673 \\
& X1.2 & 0,867 & & & \\
& X1.3 & 0,814 & & & \\
& X1.4 & 0,803 & & & \\
& X1.5 & 0,759 & & & \\
Transformational leadership & X2.1 & 0,853 & 0,883 & 0,915 & \\
(X2) & & & & & \\
& X2.2 & 0,830 & & & \\
& X2.3 & 0,854 & & & \\
& X2.4 & 0,841 & & & \\
Innovation performance (Y) & Y2.5 & 0,746 & & & \\
& Y2 & 0,851 & 0,866 & & \\
& Y3 & 0,932 & & & \\
\end{tabular}

\section{Hypothesis Testing}

Hypothesis testing in PLS is also called the inner model test. This test includes a significance test for direct and indirect effects as well as measuring the magnitude of the influence of exogenous variables on endogenous variables. To determine the effect of transactional leadership and transformational leadership on lecturers' innovation performance, a direct and indirect effect test is needed. The effect test was carried out using the t-statistic test in the partial least squared (PLS) analysis model. With the bootstrapping technique, the $\mathrm{R}$ Square value and the significance test value were obtained as shown in Table 4 below.

Table 4. Value of R Square

\begin{tabular}{ccc}
\hline & R Square & R Square Adjusted \\
\hline Innovation performance $(\mathrm{Y})$ & 0,650 & 0,644 \\
\hline
\end{tabular}

Based on Table 4 above, the value of $R$ Square innovation performance $(Y)$ is 0,650 , which means that the innovation performance variable $(Y)$ can be explained by the transactional leadership $(X 1)$ and transformational leadership (X2) variables of $65,0 \%$, while the remaining $35,0 \%$ is explained by other variables not discussed in this study. Meanwhile, Table 5 shows the T Statistics and P-Values which show the influence between the research variables that have been mentioned. 
Table 5. Hypotheses Testing

\begin{tabular}{clccccc}
\hline Hypotheses & Relationship & Beta & SE & $\begin{array}{c}\text { T } \\
\text { Statistics }\end{array}$ & $\begin{array}{c}\text { P- } \\
\text { Values }\end{array}$ & Decision \\
\hline H1 & X1 -> Y & 0,271 & 0,117 & 2,308 & 0,021 & Supported \\
H2 & X2 -> Y & 0,559 & 0,110 & 5,066 & 0,000 & Supported \\
\hline
\end{tabular}

The construct of transactional leadership (X1) has a positive influence on the construct of innovation performance, where this case is proven by the original sample value (Beta) in the value of 0,271 , which means there is a positive relationship between the construct. The T-Statistics value of this constructed relationship is 2,308 with the $T$ value of 1,96 at the significance level of $5 \%$ because the criteria for this T-statistics value should be $>1.96$ and P-Value $0,021<0,05$, hence the calculation result above shows that the effect of transactional leadership on lecturer innovation performance is considered to be significant. Therefore, the first hypothesis $\left(\mathrm{H}_{1}\right)$ is accepted.

The construct of transformational leadership has a positive influence on the construct of innovation performance, where this case is proven by the original sample value (Beta) in the value of 0,559 , which means there is a positive relationship between the construct. The T-Statistics value of this constructed relationship is 5,066 with the $T$ value of 1,96 at a significance level of $5 \%$ because the criteria for this T-statistics value should be $>1,96$ and P-Value $0,000<0,05$, hence the calculation result above shows that the effect of transformational leadership on innovation performance is considered to be significant. Therefore, the second hypothesis $\left(\mathrm{H}_{2}\right)$ is accepted.

The most interesting finding from this study is the real effect of university organizational leadership on the innovation performance of lecturers in university. They have perceptions of job prestige, self-esteem, workplace autonomy, and professional self-development that contribute the most to their innovation capabilities. These findings support previous research that revealed a significant positive relationship between aspects of leadership and innovation (Gumusluoglu \& Ilsev, 2009; Kearney, 2017; Masood \& Afsar, 2017; Ullah et al., 2016), as well as an analysis of the effect of transactional/transformational leadership on teaching performance in university and school education (Bernarto et al., 2020). These researchers argue that motivators, which refer to intrinsic aspects of teaching such as lecturers' self-growth, personal development, and recognition, tend to promote job satisfaction.

The cleanliness factor, which is related to the external aspect of the job as poor working conditions, tends to lead to lecturer dissatisfaction (Ong et al., 2020). Future studies should investigate the concept of lecturer job satisfaction by differentiating its constituents, as has been done in many studies. In the current study, overall job satisfaction, including aspects of self-fulfillment with both internal and physical aspects of the job, was examined. Further research should be carried out to clarify the concept of job satisfaction as reported by Hazriyanto \& Ibrahim (2019); Jordan et al. (2017); Nasir et al. (2017), there is heterogeneity between lecturers and concerning what they find satisfying.

\section{CONCLUSION}

Implications and conclusions these findings, on the one hand, support research conducted elsewhere, such as research Mahmood et al. (2020) which shows that lecturers prefer to work with leaders who are exhibits a transformational type of behavior. But also, this study provides clarification that lecturers also need a transactional leadership style. However, this finding should come as no surprise as actors acting as transformational leaders appear to be maximizing the autonomy that lecturers have had for a long time. 
Dewiana Novitasari: The Role of Leadership ...

However, the findings of this study remind us all that the two types of leadership examined in this study are needed as one. Because sometimes lecturers need orders and leadership that are very instructional and transactional. However, lecturers indeed feel the effect of transformational leadership is almost twice as large as the effect of transactional leadership styles. So, the findings regarding the preference of lecturers for transformational leaders appear to strengthen organizational structure and function. This research invites the world of education to pay attention to the inner realm of the lecturers. This study suggests that university management needs to pay attention to factors related to all aspects of leadership, especially the clarity of duties and responsibilities given to lecturers, motivation to achieve performance targets, and turn university leaders into a figure of an education coach.

\section{REFERENCES}

Al-Husseini, S., El Beltagi, I., \& Moizer, J. (2019). Transformational leadership and innovation: the mediating role of knowledge sharing amongst higher education faculty. International Journal of Leadership in Education, OO(00), 1-24. https://doi.org/10.1080/13603124.2019.1588381

Al-Mansoori, R. S., \& Koç, M. (2019). Transformational leadership, systems, and intrinsic motivation impacts on innovation in higher education institutes: Faculty perspectives in engineering colleges. Sustainability (Switzerland), 11(15). https://doi.org/10.3390/su11154072

Anning-Dorson, T. (2016). Interactivity innovations, competitive intensity, customer demand and performance. International Journal of Quality and Service Sciences, 8(4), 536-554. https://doi.org/10.1108/IJQSS-11-2015-0075

Asbari, M. (2020). Is Transformational Leadership Suitable for Future Organizational Needs? International Journal of Sociology, Policy and Law (IJOSPL), 01(01), 51-55.

Asbari, M., \& Novitasari, D. (2020). The Role of Readiness for Change on Part-Timer Employee Performance: Analysis of Transformational Leadership Practice in Convection Industry. Journal of Communication Education (JOCE), 14(2).

Asbari, M., Prasetya, A. B., Santoso, P. B., \& Purwanto, A. (2021). From Creativity to Innovation: The Role of Female Employees' Psychological Capital. International Journal of Social and Management Studies (IJOSMAS), 02(02), 66-77.

Asbari, M., Santoso, P. B., \& Prasetya, A. B. (2020). Elitical and Antidemocratic Transformational Leadership Critics: Is It Still Relevant? (A Literature Study). International Journal of Sociology, Policy and Law (ljospl), 01(01), 11-16. https://doi.org/10.8888/ijospl.v1i1.10

Bass, B., \& Avolio, B. (2000). Technical Report, Leader form, rater form, and Scoring Key of MLQ From $5 x$ Short. Mind Garden, Inc.

Bass, B. M. (1985). Leadership: Good, Better, Best. Organizational Dynamics, 13(3), 26-40.

Bogler, R. (2001). The Influence of Leadership Style on Teacher Job Satisfaction. Educational Administration Quarterly, 37(5), 662-683. https://doi.org/10.1177/00131610121969460

Elrehail, H. (2018). The Relationship Among Leadership, Innovation and Knowledge Sharing: A Guidance for Analysis. Data in Brief, 19, 128-133. https://doi.org/10.1016/j.dib.2018.04.138

Ghozali, I. (2014). Structural Equation Modeling, Metode Alternatif dengan Partial Least Square (PLS) (4th ed.). Badan Penerbit Universitas Diponegoro.

Gumusluoglu, L., \& Ilsev, A. (2009). Transformational leadership, creativity, and organizational innovation. Journal of Business Research, 62(4), 461-473.

Hazriyanto, \& Ibrahim, B. (2019). The factor analysis of organizational commitment, job satisfaction and performance among lecturers in Batam. Journal of Technical Education and Training, 11(1), 151158. https://doi.org/10.30880/jtet.2019.11.01.19

Jordan, G., Vukovič, G., \& Marič, M. (2017). Effect of Meaning of Work on Job Satisfaction: Case of 
Lecturers in Higher Education In Six CEE Countries. The Twelfth International Conference: Innovative Responses for Growth and Competitiveness.

Kearney, J. (2017). An Investigation into the Associative Relationship Between Transformational Leadership and Innovative Working Behaviour, in Irish Technology Consulting Organisations. National College of Ireland. http://norma.ncirl.ie/2869/1/jeremykearney.pdf

Leithwood, K., \& Jantzi, D. (2009). Transformational Leadership. The Essentials of School Leadership, 28, 37-52. https://doi.org/10.4135/9781446288290.n3

Mahmood, S., Muhammad, R., \& Farooq, A. (2020). Investigating the impact of Transformational Leadership on Employee Innovative Behavior and Job Performance: The mediating role of Public Service Motivation Abstract : 40(1), 455-465.

Mansury, M. A., \& Love, J. H. (2008). Innovation, productivity and growth in US business services: A firmlevel analysis. Technovation, 28(1-2), 52-62. https://doi.org/10.1016/j.technovation.2007.06.002

Masood, M., \& Afsar, B. (2017). Transformational leadership and innovative work behavior among nursing staff. Nursing Inquiry, 24(4). https://doi.org/10.1111/nin.12188

Nasir, M. J. A., Wiyono, B. B., Supriyono, \& Supriyanto, A. (2017). The Relationship between Motivation, Organisational Commitment and Competence with Job Satisfaction and Lecturers Performance. International Journal of Learning and Development, 7(3), 165. https://doi.org/10.5296/ijld.v7i3.11688

Ong, F., Purwanto, A., Supono, J., Hasna, S., Novitasari, D., \& Asbari, M. (2020). Does Quality Management System ISO 9001:2015 Influence Company Performance? Answers from Indonesian Tourism Industries. Test Engineering and Management, 83, 24808-24817.

Rajapathirana, R. P. J., \& Hui, Y. (2018). Relationship between innovation capability, innovation type, and firm performance. Journal of Innovation and Knowledge, 3(1), 44-55. https://doi.org/10.1016/j.jik.2017.06.002

Sasono, I., \& Novitasari, D. (2020). Enhancing Service Quality through Innovation Capabilities and Work Productivity. International Journal of Science and Management Studies (IJSMS), 3(5), 123-133. https://doi.org/10.51386/25815946/ijsms-v3i6p111

Ullah, M. I., Hamid, K. B. A., \& Shahzad, A. (2016). Impact of Transformational Leadership on Knowledge Sharing of Employees and Innovation Capability in the Dairy Sector of Pakistan. Pakistan Journal of Social Sciences, 36(1), 87-98.

Wang, Y., Song, J., Baker, J., \& Kim, Y. (2018). The Role Of Service Standardization Capability In Service Innovation: Evidence From Knowledge-Intensive Service Firms. AlS elibrary. https://aisel.aisnet.org/amcis2018/DigitalAgility/Presentations/6/

Wu, I. L., \& Hu, Y. P. (2018). Open Innovation Based Knowledge Management Implementation: A Mediating Role of Knowledge Management Design. Journal of Knowledge Management, 22(8), 1736-1756. https://doi.org/10.1108/JKM-06-2016-0238 
